Ю.С. Репіло, О.В. Головченко

Національний університет оборони Украӥни ім. І. Черняховського, Київ

\title{
ОБҐРУНТУВАННЯ ПОКАЗНИКІВ ТА КРИТЕРІЮ МОЖЛИВОЇ ЖИВУЧОСТІ АРТИЛЕРІЙСЬКИХ ПІДРОЗДІЛІВ ПІД ЧАС ВОГНЕВОЇ ПІДТРИМКИ В НАСТУПАЛЬНИХ ДІЯХ
}

У статті в загальному вигляді обтрунтовано показники і критерій можливої живучості артилерійських підрозділів під час вогневої підтримки. Показником можливої живучості артилерійських підрозділів передбачається врахування стохастичності процесу ведення наступальних дій загальновійськовими формуваннями під час виконання ними оперативних (тактичних) завдань у наступі (контрнаступі). За критерій можливої живучості артилерійських підрозділів визначено математичне сподівання потрібної кількості збережених артилерійських підрозділів під час виконання загальновійськовими формуваннями оперативних (тактичних) завдань, у ході яких буде забезпечено їх вогневу підтримку з потрібною ефективністю для досягнення мети наступальних дій. Запропоновані показники та критерій можуть бути використані в інтересах розроблення науково-методичного апарату для очінювання можливої живучості артилерійських підрозділів під час їх застосування в операціях та обгрунтування відповідних рекомендацій щзодо забезпечення їх живучості під час вогневої підтримки в наступальних діях.

Ключові слова: показник, критерії, живучість, вогнева підтримка, наступальні діі.

\section{Вступ}

Постановка проблеми. Практика застосування складних систем військового призначення у ході ведення збройної боротьби, у тому числі артилерійських підрозділів (АП), показує, що проблема забезпечення необхідної ефективності застосування та забезпечення їх живучості має першорядне значення [1-8]. У свою чергу враховуючи, що цикл оновлення засобів ведення збройної боротьби, в тому числі і артилерійських систем, становить не менше 10 років [9-10], нагальним завданням на період до 2030 року $є$ дослідження питань забезпечення живучості без зниження ефективності застосування військових формувань артилерії зі складу систем військового призначення. Поряд з тим, актуальності дослідженням питань забезпечення можливої живучості АП додає той факт, що ці питання в порівнянні $з$ теорією дослідження ефективності застосування військових формувань артилерії, на даний час вирішуються лише фрагментарно без об'єднання отриманих результатів у єдину систему.

В умовах трансформації Збройних Сил України та їх переходу на принципи і стандарти НАТО, де основним видом воєнних дій є наступ, особливе місце серед задач, що отримали актуальність в теорії воєнного мистецтва на даний час, займають наукові завдання, пов'язані із забезпеченням живучості складних систем військового призначення саме в наступальних діях, а АП в цьому відношенні не $є$ винятком. Однак, розв'язок даного завдання можливий лише за результатами дослідження з викорис- танням відповідного науково-методичного апарату щодо оцінювання впливу чинників зовнішнього та внутрішнього середовища на живучість АП.

Аналіз останніх досліджень і публікацій. Аналіз наукових публікацій 3 питань розв'язання даного завдання показав, що дослідженню закономірностей впливу чинників зовнішнього та внутрішнього середовища на живучість складних систем військового призначення присвячено низку досліджень [11-13]. При цьому, в своїй більшості вони стосуються забезпечення живучості під час ведення бойових дій не АП, а лише підрозділів зі складу угруповання військ протиповітряної оборони. Результати аналізу існуючих підходів, моделей та методик оцінювання живучості, дозволяють стверджувати, що такі підходи не дозволяють враховувати низку чинників, що характерні під час ведення бойових дій саме АП. Тобто, існуючий науковометодичний апарат оцінювання можливої живучості складних систем військового призначення у наявному вигляді не може бути використаний в інтереcax дослідження живучості АП, але може бути використаний як базовий для подальшого удосконалення. При цьому, первинним щодо удосконалення виступає уточнення системи показників та критерію можливої живучості АП при заданій ефективності вогневої підтримки з закритих вогневих позицій.

Мета статті полягає в обгрунтуванні показників та критерію можливої живучості артилерійських підрозділів під час вогневої підтримки в наступальних діях. 


\section{Виклад основного матеріалу}

Живучість складних систем військового призначення у традиційному розумінні - це їх властивість зберігати або швидко відновлювати боєздатність [14]. Проте дотепер однозначного тлумачення поняття “живучості артилерійських підрозділів" в теорії воєнного мистецтва не визначено. Так, у [15] живучість системи визначається як спроможність системи до збереження своїх основних функцій навіть за умов зниженої ефективності системи, впливу факторів катастрофічного характеру. У [16] авторами дано визначення поняття живучості як здатність системи адаптуватися до нових умов, що змінилися, $\mathrm{i}$, як правило, непередбачених ситуацій, протистояти шкідливим впливам, виконувати при цьому свою цільову функцію, за рахунок відповідної зміни структури та поведінки системи. В публікації [17] зазначено, що живучість характеризує здатність системи функціонувати в умовах виходу з ладу утворюючих іiі елементів під впливом зовнішнього середовища. У словнику [18] як живучість ракетних військ і артилерії визначено здатність ракетних і артилерійських з'єднань (частин, підрозділів) зберігати чи швидко відновлювати боєздатність. В арміях країн НАТО під живучістю розуміють бойову здатність системи уникати чи протистояти несприятливим воєнним діям, які можуть призвести до втрати здатності продовжувати ефективне виконання призначеної місії [19-20].

Проведений аналіз найбільш уживаних визначень живучості складних систем військового призначення дає змогу виділити два спільні аспекти. Сутність першого полягає у здатності “внутрішнього” збереження та відновлення в умовах негативного впливу. Другий аспект - можливістю впливу на "зовнішнє” середовище, в якому сама система функціонує. Виходячи з цього, в дослідженні під “живучістю артилерійських підрозділів” прийнято його здатність зберігати та відновлювати виконання ним функції в заданому об'ємі та протягом заданого часу у разі зміни його бойового складу під час ведення бойових дій внаслідок вогневого впливу противника.

Відомо, що властивість здатності будь-якого об'єкту в повній мірі проявляється лише в процесі його застосування за призначенням, тобто в процесі його цільового функціонування. Однак, результати досліджень [21] свідчать, що живучість складних систем військового призначення, якими є АП, а також різноплановість завдань вогневої підтримки, що ними виконуються в наступальних діях, практично неможливо оцінити лише за одним показником. Виходячи з цього, пропонується для оцінювання живучості АП в складних умовах наступальних дій використовувати певну систему показників: основний (інтегральний); узагальнені (найбільш представни- цькі), які характеризують кінцевий результат функціонування АП; декілька додаткових, які характеризують ефективність їх застосування. При цьому основний показник живучості повинен бути узгодженим за формою та змістом із показником ефективності надсистеми у цілому та давати змогу оцінювати вплив живучості АП на досягнення мети ведення ними бойових дій.

Результати аналізу теорії та практики збройної боротьби в наступальних діях за ознакою суті і мети ведення бойових дій АП, свідчать, що головним змістом таких дій є цілеспрямований процес їх участі у вогневій підтримці загальновійськових формувань 3 закритих вогневих позицій. У [22-24] визначено, що вогнева підтримка - це вогонь, щодо підтримки дій загальновійськових формувань, метою якого є ураження живої сили та вогневих засобів противника, порушення бойових порядків його підрозділів підтримки під час виконання ними тактичних та оперативно-тактичних завдань. 3 цього виходить, що ведення бойових дій артилерії в наступі, здійснюється 3 метою виконання певного обсягу завдань вогневої підтримки з закритих вогневих позицій та $є$ надсистемою по відношенню до системи забезпечення живучості АП. На цій підставі, можна зробити висновок, що основний показник живучості АП повинен давати змогу оцінити не лише результативність способів забезпечення живучості АП в наступальних діях, а й їх вплив на ефективність вогневої підтримки в наступальних діях. Тобто, оцінювання результативності заходів забезпечення можливої живучості АП під час вогневої підтримки в наступальних діях доречно оцінювати за величиною можливої ефективності вогневої підтримки $\Delta W_{F S}$, приріст якої пропонується визначати за таким виразом:

$$
\Delta W_{F S}=\frac{W_{F S}^{\exp }-W_{F S}^{F M}}{W_{F S}^{F M}},
$$

де $W_{F S}^{\exp }$ - ступінь реалізації вогневих можливостей АП з вогневої підтримки під час забезпечення живучості у ході ведення бойових дій удосконаленим способом;

$W_{F S}^{F M}$ - ступінь реалізації вогневих можливостей АП з вогневої підтримки під час забезпечення живучості у ході ведення бойових дій способом, визначеним у керівних документах.

Використання виразу (1) дає змогу оцінити вплив доцільного способу забезпечення живучості АП на можливу ефективність вогневої підтримки через обсяг вогневих завдань, які можуть бути покладені на АП під час виконання оперативних (тактичних) завдань загальновійськових формувань в наступальних діях.

Враховуючи стохастичність процесу збройної боротьби в різних формах ведення воєнних дій, об- 
грунтування показників живучості АП у загальному вигляді пропонується здійснити 3 використанням теорії ймовірностей.

Виходячи 3 цього, узагальненим показником можливої живучості АП під час вогневої підтримки в наступальних діях пропонується прийняти математичне сподівання кількості артилерійських підрозділів, які ймовірно збережуть свою боєздатність до моменту закінчення вогневої підтримки під час виконання оперативних (тактичних) завдань в наступальних діях тривалістю $t_{F S}\left(M_{F A}^{c c}\left(t_{F S}\right)\right)$.

Значення узагальненого показника можна розрахувати за таким виразом:

$$
M_{F A}^{c c}\left(t_{F S}\right)=n_{F A}-M_{F A}^{l c c}\left(t_{F S}\right),
$$

де $n_{F A}$ - загальна кількість АП, виділених для виконання завдань вогневої підтримки в наступальних діях;

$$
M_{F A}^{l c c}\left(t_{F S}\right) \text { - математичне сподівання кількості }
$$

АП, які можуть втратити свою боєздатність до моменту закінчення вогневої підтримки в наступальних діях $з$ причин завдання їм ураження вогневими засобами противника.

Вважається, що зазначений показник має чіткий фізичний зміст і дозволить адекватно оцінити ймовірну живучість АП під час ведення бойових дій у ході виконання оперативних (тактичних) завдань для досягнення мети воєнних дій у різних їх формах. Однак з метою забезпечення повноти даних для досліджень способів забезпечення живучості (маскування АП, здійснення маневру, тощо) виникає потреба у виявлені кількісних характеристик складових такої живучості для прийняття раціонального рішення мірою яких виступає критерій можливої живучості. Виходячи 3 цього, критерієм можливої живучості АП у ході ведення наступальних дій пропонується прийняти математичне сподівання кількості збережених АП при заданих втратах артилерійських систем зі складу військового формування артилерії при якому забезпечується вогнева підтримка із ефективністю, що вимагається при вогневому впливі на об'єкти противника:

$$
\left\{\begin{array}{l}
M_{F A}^{c c}\left(t_{F S}\right) \geq M_{F A}^{r c c}\left(t_{F S}\right) \\
M_{F A}\left(t_{F S}\right) \geq M_{F A}^{r}\left(t_{F S}\right)
\end{array},\right.
$$

де $M_{F A}^{r}\left(t_{F S}\right)$ - потрібне значення математичного сподівання величини максимального збитку, завданого АП об'єктам противника у ході вогневої підтримки виконання загальновійськовими формуваннями оперативних (тактичних) завдань загальновійськовими формуваннями в наступальних діях.

Для прикладу, за відомою залежністю з теорії стрільби [25], визначення значення такої величини залежно від тривалості вогню пропонується визна- чити за таким виразом:

$$
W_{F A}\left(t_{F S}\right)=\frac{1}{19 \alpha^{\prime}+1} .
$$

При цьому, зробивши припущення, що величина середньої ураженої площі знаходиться в інтервалі $0,05 \ldots 0,7$, значення параметру $\alpha^{\prime}$ пропонується розраховувати за таким виразом:

$$
\alpha^{\prime}=\frac{E_{x_{0}}^{\prime} E_{y_{0}}^{\prime}}{m \lambda_{m} t_{F S} S \tau},
$$

де $E_{x_{0}}^{\prime}, E_{y_{0}}^{\prime}$ - серединні повторювані помилки 3 урахуванням розмірів об'єкта, м;

m - кількість гармат;

$\lambda_{m}$ - постійна швидкострільність однієї гармати (кількість пострілів за 1 хв);

$t_{F S}$ - час, протягом якого здійснюється вогневий вплив, хв;

$S$ - площа приведеної зони ураження елементарної цілі зі складу об'єкта, м²

$\tau$ - поправочний коефіцієнт, що залежить від приведених розмірів цілі.

Тоді, розрахунок $E_{x_{0}}^{\prime}, E_{y_{0}}^{\prime}$ з врахуванням серединних повторюваних помилок з врахуванням розміру об'єкта пропонується визначати за такими виразами:

$$
\begin{aligned}
& E_{x_{0}}^{\prime}=E_{x_{0}} \sqrt{1+0,15\left(\frac{L_{x}}{E_{x_{0}}}\right)^{2}} ; \\
& E_{y_{0}}^{\prime}=E_{y_{0}} \sqrt{1+0,15\left(\frac{L_{y}}{E_{y_{0}}}\right)^{2}},
\end{aligned}
$$

де $E_{x_{0}}^{\prime}, E_{y_{0}}^{\prime}$ - серединні повторювані помилки, м;

$L_{x}-1 / 2$ розміру глибини об'єкта, м;

$L_{y}-1 / 2$ розміру фронту об'єкта, м.

В якості прикладу у табл. 1 наведено значення математичного сподівання величини максимального середнього збитку, якого буде завдано по живій силі противника, що перебуває у взводному опорному пункті розміром 300 м за фронтом і глибиною, залежно від тривалості ведення вогню по ній. До ведення вогню залучено артилерійський дивізіон трьох батарейного складу, коли кожна батарея має 6 гармат при підготовці даних способом повної підготовки. Дальність стрільби становить 7500 м.

Аналізуючи дані табл. 1, можна зробити висновок, що зі збільшенням часу вогневого впливу по цілі від 1 до 5 хв величина відповідного приросту збитку їй змінюється, практично, за лінійною залежністю (наприклад, для $2 \mathrm{~A} 36$ з 3,8\% до 16,3\%), однак після 5 хв ведення вогню такий приріст різко зменшується. 
Таблиця 1

Математичне сподівання величини завдавання максимального збитку живій силі противника залежно від тривалості ведення вогню по ній, \%

\begin{tabular}{|c|c|c|c|c|c|}
\hline $\begin{array}{c}\text { Тривалість } \\
\text { ведення } \\
\text { вогню по } \\
\text { живій силі } \\
t_{F S}\end{array}$ & $\begin{array}{c}2 \mathrm{C} 1 \\
\text { (ОФ-462) }\end{array}$ & $\begin{array}{c}2 \mathrm{C} 1 \\
(\text { ОФ24) }\end{array}$ & $\begin{array}{c}\text { Д-20 } \\
\text { (ОФ-540) }\end{array}$ & $\begin{array}{c}\text { Д-20 } \\
(\text { ОФ-25) }\end{array}$ & $\begin{array}{c}\text { 2А36 } \\
\text { (ОФ29) }\end{array}$ \\
\hline 1 хв & 2 & 2,6 & 2,9 & 3,5 & 3,8 \\
\hline 3 хв & 5,7 & 7,5 & 8,3 & 9,8 & 10,5 \\
\hline 5 хв & 9 & 11,8 & 13,1 & 15,4 & 16,3 \\
\hline 10 хв & 16 & 17,3 & 18,5 & 21,4 & 27 \\
\hline 15 хв & 18,5 & 23,2 & 23,2 & 26,7 & 31,9 \\
\hline
\end{tabular}

Джерело: розроблено авторами за даними $[25$, с. $107 ; 26$, с. $68 ; 27$, с. $240 ; 28$, с. $17-61 ; 29$, с. 29 $122 ; 30$, c. $9-43 ; 31$, c. $205-215]$.

Тоді, враховуючи, що після 5 хв різко зростає ймовірність відкриття противником вогню у відповідь, “ціна” продовження подальшого вогню нашою артилерією досить висока через можливу втрату нею живучості. 3 урахуванням цього частковими показниками можливої живучості АП пропонується прийняти $M_{F A}^{c c}\left(t_{F S}\right)$ - математичне сподівання кількості АП, які втратили свою боєздатність до моменту закінчення виконання завдань вогневої підтримки в наступальних діях через їх ураження вогневими засобами противника при заданих втратах, та $M_{F A}^{c c}\left(t_{F S}\right)$ - математичне сподівання кількості об'єктів противника, яку можна прийняти до ураження АП при обраному способі забезпечення живучості 3 урахуванням потрібного значення математичного сподівання величини максимального середнього збитку, завданого об'єктам противника.

У той же час, величину математичного сподівання кількості типових об'єктів, що можуть бути прийняті до ураження АП, пропонується визначати за такою залежністю:

$$
M_{F A}^{c c}\left(t_{F S}\right)=\frac{t_{c}}{t_{F S}} P_{F S}
$$

де $t_{c}$ - час виконання оперативного (тактичного) завдання в наступальних діях, хв;

$t_{F S}$ - тривалість виконання типового вогневого завдання при заданій ефективності вогневої підтримки (з урахуванням часу, потрібного на маневр для виконання наступного завдання), хв;

$P_{F S}$ - ймовірність перебування АП у стані виконання завдань вогневої підтримки.

При цьому, розрахунок математичного сподівання кількості АП, які втратили свою боєздатність через завдання їм ураження засобами противника можливо здійснити за виразом:

$$
M_{F A}^{l c c}\left(t_{F S}\right)=\sum_{i=1}^{n_{F A_{i}}} M_{F A_{i}}^{l c c}\left(t_{F S}\right) .
$$

Вважається, що запропонована формалізація основних процесів забезпечення живучості артилерійських підрозділів відбиває їх фізичну суть для проведення подальших досліджень.

\section{Висновки}

Таким чином, у статті запропоновано підхід до обгрунтування показників та критерію можливої живучості АП під час вогневої підтримки в наступальних діях, які можуть слугувати базою для виробки пропозицій щодо підвищення живучості артилерійських підрозділів для досягнення ними цілей вогневої підтримки загальновійськових формувань під час ведення наступальних дій.

При цьому, на думку авторів, доцільним напрямом подальших досліджень $є$ розроблення науковометодичного апарату оцінювання можливої живучості складних систем військового призначення, за допомогою якого передбачається враховувати причинно-наслідкові зв'язки між складовими процесу застосування артилерійських підрозділів у наступальних діях, що дасть змогу одержати ймовірні значення показника можливої живучості, які валідні реальному процесу їх застосування в операції (бою).

\section{Список літератури}

1. Maistrenko O., Karavanov O., Riman O., Kurban V., Shcherba A., Volkov I., Kravets T., Semiv G. Devising a procedure for substantiating the type and volume of redundant structural-functional elements of reconnaissance-firing systems. Eastern-European Journal of Enterprise Technologies. 2021. No. 2(110). P. 31-42. https://doi.org/10.15587/1729-4061.2021.229031.

2. Репіло Ю. Є., Головченко О. В. Модель ведення бойових дій артилерійськими підрозділами під час вогневої підтримки у ході ведення наступальних дій. Сучасні інформаційні технології у сфері безпеки та оборони. 2021. № 1(40). C. 153-162. https://doi.org/10.33099/2311-7249/2021-40-1-153-162.

3. Репіло Ю., Головченко О., Іщенко О. Контент-аналіз уроків збройного конфлікту в Нагірному Карабасі щодо вогневої підтримки військових формувань Азербайджану в наступальних діях. Збірник наукових прачь Наиіональної академії Державної прикордонної служби України. 2021. № 84(1). C. 86-99. https://doi.org/10.32453/3.v84i1.805.

4. Коцюруба В. І., Кривцун В. І. Математична модель визначення бойового функціонування блочної загороджувальної перешкоди. Системи озброєння і військова техніка. 2019. № 2(58). С. 33-37. https://doi.org/10.30748/ soivt.2019.58.05.

5. Теоретичні основи управління угрупованням військ (сил) у сучасних умовах збройної боротьби : монографія / Загорка О. М., Корецький А. А., Павліковський А. К., Загорка І. О.; за ред. І. С. Руснака. Київ : НУОУ імені Івана Черняховського, 2020. 248 c. 
6. Петухов Г. Б., Якунин В. И. Методологические основы внешнего проектирования целенаправленных процессов и целеустремленных систем. Москва : АСТ, 2006. 504 с.

7. Голованов А. В., Скородід С. П. Обгрунтування показника оцінювання варіантів розподілу сил і засобів за напрямками у смузі оборони. Збірник наукових прачь Харківського національного університету Повітряних Сил. 2019. № 2(60). C. 16-21. https://doi.org/10.30748/zhups.2019.60.02.

8. Майстренко О. В., Репіло Ю. С., Демидко Д. Л. Визначення області доцільних значень для показників точності та раптовості вогню артилерії (ударів ракет). Сучасні інформачійні технології у сфері безпеки та оборони. 2015 . № 1. C. 79-82. URL: http://nbuv.gov.ua/UJRN/sitsbo_2015_1_15 (дата звернення: 12.06.2021).

9. Репіло Ю. С. Бойове застосування ракетних військ і артилерії: досвід, реальність і перспективи : монографія. Київ : НАОУ, 2006. 280 с.

10. Оборонне планування на основі спроможностей: навч. посіб. / кол. авт. Київ : НУОУ імені Івана Черняховського, $2020.96 \mathrm{c}$.

11. Гогонянц С. Ю., Крищенко В. М. Методика оцінювання живучості угруповання радіотехнічних військ під час участі у відбитті удару повітряного противника. Збірник наукових праць Харківського національного університету Повітряних Сил. 2018. № 3(57). С. 8-13. https://doi.org/10.30748/zhups.2018.57.01.

12. Загорка О. М., Коваль В. В., Загорка І. О. Методичні положення оцінки живучості зенітної ракетної системи від дії по ії елементах засобів ураження противника. Збірник наукових працьь Харківського національного університету Повітряних Сил. 2017. № 4(53). С. 13-16. URL: http://www.hups.mil.gov.ua/periodic-app/article/17778 (дата звернення: 12.06.2021).

13. Титаренко О. Б., Гогонянц С. Ю. Окремі положення удосконаленої методики оцінки живучості угруповання зенітних ракетних військ при відбитті удару засобів повітряного нападу противника. Наука і техніка Повітряних Сил Збройних Сил України. 2015. № 1(18). C. 45-48. URL: http://www.hups.mil.gov.ua/periodic-app/article/744 (дата звернення: 12.06.2021).

14. Титаренко О. Б., Місюра О. М., Тристан А. В. Обгрунтування шляхів підвищення живучості систем зенітного ракетного прикриття при відбитті удару засобів повітряного нападу противника. Системи озброєння $і$ військова техніка. 2014. № 1(37). C. 76-80. URL: http://nbuv.gov.ua/UJRN/soivt_2014_1_19 (дата звернення: 12.06.2021).

15. Звіт про науково-дослідну роботу "Розробка воєнного енциклопедичного словника. Відбір і розроблення визначень термінів у воєнний енциклопедичний словник” (проміжний звіт). Київ : НАОУ, 2007. 256 с.

16. Додонов А. Г., Ландэ Д. В. Живучесть информационных систем. Київ : Наук. думка, 2011. 256 с.

17. Атрохов А. В., Вернер І. Е., Гавалко В. І. та ін. Основи моделювання бойових дій військ: підручник. Київ : HAOУ, 2005. $484 \mathrm{c}$.

18. Словарь ракетных и артиллерийских терминов. Москва : Воениздат, 1988. 256 с.

19. AR 70-75 Survivability of Army Personnel and Materiel, 29 April 2019. web site. URL: https://armypubs.army.mil (accessed 24.02.2021).

20. Репіло Ю. Є., Майстренко О. В., Адаменко М. В. Еволюція змісту принципів застосування військових формувань ракетних військ і артилерії під час вогневого ураження противника. Сучасні інформаційні технології у сфері безпеки та оборони. 2016. № 1. C. 185-191. URL: http://nbuv.gov.ua/UJRN/sitsbo_2016_1_36 (дата звернення: 12.06.2021).

21. Репіло Ю. Є., Ріман О. О., Демидко Д. Л. Підхід до оцінювання ефективності вогневого ураження позицій безпілотних авіаційних комплексів противника ракетними військами і артилерією. Сучасні інформачійні технологї̈ у сфері безпеки та оборони. 2015. № 1. C. 98-102. URL: http://nbuv.gov.ua/UJRN/sitsbo_2015_1_18 (дата звернення: 12.06.2021).

22. Погляди провідних фахівців НАТО на вогневу підтримку з закритих вогневих позицій : монографія / Репіло Ю. Є. та ін. Київ : НУОУ ім. Івана Черняховського, 2018. 196 с.

23. FM 3-09 Fire Support and Field Artillery Operations, 30 April 2020. web site. URL: https://armypubs.army.mil (accessed 12.06.2021).

24. STANAG 2484 AARTYP-05 Ed B, NATO Fire Support Doctrine: 05 November 2015. web site. URL: https://standards.globalspec.com/std/9983890/STANAG\%202484.

25. Фендриков Н. М., Яковлев В. И. Методы расчетов боевой эффективности вооружения. Москва : Воениздат, 1971. $224 \mathrm{c}$.

26. Матвеев А. И., Малаховский Е. К. Стрельба на поражение батарей. Москва : Воениздат, 1971. 168 с.

27. Балаганский И. А., Мержиевский Л. А. Действия средств поражения и боеприпасов : учебник. Новосибирск : НГТУ, 2004. 253 с.

28. Таблицы стрельбы 122-мм самоходной гаубицы 2С1, ТС № 0141. Изд. 2-е. Москва : Воениздат, 1984. 256 с.

29. Таблицы стрельбы для равнинных и горных условий 152-мм пушки-гаубицы Д-20, ТС РГ № 271. Москва : Воениздат, 1991. 368 с.

30. Таблицы стрельбы для равнинных и горных условий 152 -мм самоходной пушки 2 С5 и 152 -мм буксируемой пушки 2А36, ТС РГ № 273. зд. 3-е. Москва : Воениздат, 1988. 176 с.

31. Правила стрільби і управління вогнем наземної артилерії (дивізіон, батарея, взвод, гармата): затв. наказом Генерального штабу ЗС України від 05.01.2018 № 6. Київ : ГШ ЗС України, 2018. 268 с. 


\section{Репіло Юрій Євгенович} доктор військових наук професор професор кафедри Національного університету оборони України ім. Івана Черняховського, Київ, Україна

https://orcid.org/0000-0002-1393-2371

\section{Головченко Олег Володимирович}

ад'юнкт Національного університету оборони

України ім. І. Черняховського,

Київ, Україна

https://orcid.org/0000-0003-3715-7872
Iurii Repilo

Doctor of Military Sciences Professor

Professor of Department of the National Defense

University of Ukraine named after Ivan Cherniakhovskyi,

Kyiv, Ukraine

https://orcid.org/0000-0002-1393-2371

\section{Oleg Golovchenko}

Doctoral Student of the National Defense University of Ukraine named after Ivan Cherniakhovskyi, Kyiv, Ukraine

https://orcid.org/0000-0003-3715-7872

\title{
ОБОСНОВАНИЕ ПОКАЗАТЕЛЕЙ И КРИТЕРИЯ ВОЗМОЖНОЙ ЖИВУЧЕСТИ АРТИЛЛЕРИЙСКИХ ПОДРАЗДЕЛЕНИЙ ВО ВРЕМЯ ОГНЕВОЙ ПОДДЕРЖКИ В НАСТУПАТЕЛЬНЫХ ДЕЙСТВИЯХ
}

\author{
Ю.Е. Репило, О.В. Головченко
}

В статье в общем виде обоснованны показатели и критерий возможной живучести артиллерийских подразделений во время огневой поддержки. Показателем возможной живучести артиллерийских подразделений предусматривается учитывать стохастичность процесса ведения наступательных действий общевойсковыми формированиями при выполнении ими оперативных (тактических) задач в наступлении (контрнаступлении). За критерий возможной живучести артиллерийских подразделений определено математическое ожидание нужного количества сохранившихся артиллерийских подразделений во время выполнения общевойсковыми формированияли оперативных (тактических) задач, в ходе которых будет обеспечено их огневую поддержку с нужным уровнем эффективности для достижения иели наступательных действий. Предложенные показатели и критерий могут быть использованы в интересах разработки научно-методического аппарата для оценивания возможной живучести артиллерийских подразделений во время их применения в операциях и обоснования соответствующих рекомендачий по обеспечению их живучести при огневой поддержки в наступательных действиях

Ключевые слова: показатель, критерий, живучесть, огневая поддержка, наступательные действия.

\section{JUSTIFICATION OF INDICATORS AND CRITERION OF POSSIBLE SURVIVABILITY OF ARTILLERY UNITS DURING FIRE SUPPORT IN OFFENSIVE OPERATIONS}

I. Repilo, O. Golovchenko

The practice of using complex military systems during offensive operations, including artillery units, shows that the problem of ensuring the necessary efficiency of their use and survivability is key one. The relevance of the study of the possible viability of artillery units is added by the fact that the solution of these issues, compared with the theory of the study of the effectiveness of artillery, is currently fragmentary without combining the results into a single system. In this aspect, there is a scientific task of search nature, which is associated with the development of scientific and methodological apparatus, in particular methods for assessing the possible survivability of artillery units during fire support during their use in operations (combat). At the same time, the substantiation of indicators and criteria of possible survivability of artillery units during fire support in offensive operations is of paramount importance. The article in general form substantiates the indicators and the criterion of possible survivability of artillery units during fire support. The indicators of assessment of the survivability of artillery units is stochastic and makes it possible to take into account the uncertainty of offensive operations by all-military formations during their performance of operational (tactical) tasks in the offensive (counteroffensive). The criterion for assessing survivability is the mathematical expectation of the required number of surviving artillery units during the performance of operational (tactical) tasks by allmilitary formations, during which their fire support will be provided with the required level of efficiency to achieve goal in the offensive. The proposed indicators and criteria can be used in the interests of developing a scientific and methodological apparatus for assessing the survivability of artillery units during their use in operations and substantiate the relevant recommendations for ensuring their survivability during fire support in offensive operations.

Keywords: indicators, criterion, survivability, fire support, offensive operations. 